\title{
Apparent and standardised ileal digestibility coefficients of amino acids in wheat, soybean meal and rapeseed meal for broilers
}

\author{
Sini Perttilä ${ }^{1}$, Taina Jalava², Marketta Rinne ${ }^{2}$, Gabriel Da Silva Viana ${ }^{2}$ and Jarmo Valaja ${ }^{3}$ \\ ${ }^{1}$ Natural Resources Institute Finland (Luke), Latokartanonkaari 9, FI-00790 Helsinki \\ ${ }^{2}$ Natural Resources Institute Finland (Luke), Tietotie 2 C, Fl-31600 Jokioinen \\ ${ }^{3}$ University of Helsinki, Department of Agricultural Sciences, P.O. Box 28, FI-00014 Helsinki \\ e-mail: sini.perttila@luke.fi
}

\begin{abstract}
The apparent (AID) and standardised (SID) ileal amino acid digestibilities in wheat, soybean meal and rapeseed meal were determined with Ross 308 broiler chicken $(n=64)$ using the slaughter technique with chromium mordanted straw as an indigestible marker. The recovery of endogenous amino acids at the distal ileum was determined with protein-free diet and it was used to calculate the SID digestibilities of the studied feed ingredients. The mean amino acid AID and SID were higher in soybean meal and wheat than in rapeseed meal $(p<0.05)$. The mean amino acid flow measured from the ileum was the highest in rapeseed meal, intermediate in soybean meal and the lowest in wheat $(p<0.05)$. The main amino acids in the basal endogenous secretion were aspartic and glutamic acid and the lowest ones present were methionine and histidine $(p<0.05)$. The difference between amino acid AID and SID values varied among ingredients and was higher in wheat than in soybean meal and rapeseed meal $(p<0.05)$.
\end{abstract}

Key words: poultry, digestibility, ingredient, endogenous secretion

\section{Introduction}

Feed formulation based on the ileal digestibility of amino acids is preferred compared to the apparent total digestibility of amino acids (Ravindran et al. 1999, Kadim et al. 2002). Digestibility values measured from excreta may be biased by intestinal microbiota which can either synthesize protein or ferment undigested amino acids in the lower digestive tract. In this regard, digestibility of amino acids should be measured at the end of ileum where amino acids from feeds have been completely absorbed (Ten Doeschate et al. 1993, Ravindran et al. 1999).

Amino acids represent major inputs in final feed costs. Therefore broiler feeds formulated based on the digestible amino acid content optimize the supply of nitrogen, i.e., crude protein and amino acids, and decrease feed costs compared to a total amino acid based concept (Rostagno et al. 1995, Maiorka et al. 2004, Dari et al. 2005). Conventionally, ileal digestibility of amino acids has been measured ignoring the proteinaceous compounds continuously produced by the gastrointestinal tract (e.g. enzymes, sloughed epithelial cells, and mucus) and/or nitrogen reflux from large intestine. Although widely used, such approach indicated as apparent ileal digestibility (AID), may lead to misconceptions about how amino acids from diets are digested by birds. In order to design feeding programmes which optimize the utilization of dietary amino acids by poultry, such endogenous secretions should be discounted from apparent ileal digestibility (AID) and standardised amino acid ileal digestibility values (SID) should preferably be used in feed formulation.

Endogenous secretions may be divided into basal and feed-specific fractions (Lemme et al. 2004). The basal endogenous secretion can be measured using a protein-free diet (Siriwan et al. 1994, Ravindran et al. 2004), which was considered to be the most consistent and reliable method according to Adedokun et al. (2011). However, Adedokun et al. (2011) noticed that because of large variation in the materials and methods used in digestibility assays, the basal ileal endogenous amino acid flow should be determined every time simultaneously with the experimental feeds in studies where SID values are determined.

The amino acid SID values were observed to be more additive than AID values when they were used for calculating the digestibility of a complete diet in feed formulation (Kong and Adeola 2013). However, the difference between the AID and the SID values of amino acids has been shown to vary among feed ingredients, and the differences between the coefficients are larger for low digestibility and fibrous ingredients (Lemme et al. 2004, Hoehler et al. 2006). Research conducted to determine the digestibility of amino acids in feed ingredients for poultry differ from each other with respect to methodological aspects, cultivars investigated, maturity stage of birds, and even poultry species used. Expectedly, such factors affect the estimates of amino acid digestibility coefficients, whose 
reliability would, therefore, require a compilation of data from a wide range of trials. The aim of the current experiment was to investigate the apparent ileal digestibility of amino acids in feed ingredients commonly used in Northern Europe such as wheat, soybean meal and rapeseed meal. The basal amino acid composition of endogenous secretions was determined with protein-free diet and amino acid SID values were calculated.

\section{Material and methods}

All experimental procedures involving animal care and use were approved beforehand by the Animal Care Committee of the MTT Agrifood Research Finland (currently Natural Resources Institute Finland, Luke).

A total of 64 1-day-old Ross 308 broiler chicken were obtained from a commercial hatchery and used in the digestibility assay. The chicks were housed in battery cages $(48 \times 56 \times 40 \mathrm{~cm})$ with raised wire floors in an environmentally controlled room with four birds ( 2 males and 2 females) per cage. Birds were fed a commercial starter diet from day 1 to day 14 (220 g crude protein [CP] kg-1 diet; $12.6 \mathrm{MJ}^{-1}$ metabolizable energy [ME] kg-1 diet) and a commercial grower diet from day 15 to day 31 of age $\left(200 \mathrm{~g} \mathrm{CP} \mathrm{kg}^{-1}\right.$ diet; $\left.12.9 \mathrm{MJ} \mathrm{ME} \mathrm{kg}^{-1}\right)$. From day 32 to day 36 they were fed the experimental diets. Feed and water were provided ad libitum. Environmental temperature, humidity and light were controlled according to the recommendations of Ross Broiler Management Handbook (www.aviagen.com).

Dietary ingredients and chemical composition of the tested ingredients and diets used in the digestibility measurements are presented in Tables 1 and 2. The semi-purified experimental diets contained glucose, starch, cellulose, vitamins, minerals, rapeseed oil and either wheat, rapeseed meal or soybean meal as the sole protein source.

Table 1. Chemical composition of the experimental feed ingredients ( $\mathrm{g} \mathrm{kg}^{-1} \mathrm{dry}$ matter, unless otherwise stated)

\begin{tabular}{|c|c|c|c|c|c|}
\hline Feed & Wheat & Soybean meal & Rapeseed meal & Starch & Cellulose \\
\hline Dry matter $\left(\mathrm{g} \mathrm{kg}^{-1}\right)$ & 894 & 894 & 900 & 864 & 944 \\
\hline Crude protein & 147 & 470 & 357 & 1.7 & 4.0 \\
\hline Ether extract & 19 & 33 & 41 & 0.6 & 1.8 \\
\hline Crude fibre & 29 & 59 & 133 & 3.6 & 684 \\
\hline Ash & 18 & 60 & 75 & 1.1 & 0.8 \\
\hline Amino acids $\left(\mathrm{g}_{16} \mathrm{~g}^{-1} \mathrm{~N}\right)$ & & & & nd & nd \\
\hline Arginine & 4.6 & 7.1 & 6.0 & & \\
\hline Histidine & 2.5 & 2.6 & 2.7 & & \\
\hline Isoleucine & 3.7 & 4.5 & 4.0 & & \\
\hline Leucine & 6.8 & 7.8 & 7.2 & & \\
\hline Lysine & 2.8 & 6.2 & 5.6 & & \\
\hline Methionine & 1.6 & 1.4 & 2.1 & & \\
\hline Phenylalanine & 4.9 & 5.1 & 4.1 & & \\
\hline Threonine & 2.8 & 3.8 & 4.5 & & \\
\hline Valine & 6.7 & 5.3 & 5.9 & & \\
\hline Alanine & 3.5 & 4.3 & 4.5 & & \\
\hline Aspartic acid & 4.9 & 10.9 & 7.4 & & \\
\hline Cystine & 2.4 & 1.5 & 2.0 & & \\
\hline Glutamic acid & 26.7 & 18.0 & 14.3 & & \\
\hline Glycine & 4.1 & 4.1 & 5.1 & & \\
\hline Proline & 10.7 & 5.0 & 6.3 & & \\
\hline Serine & 4.7 & 5.0 & 4.3 & & \\
\hline Tyrosine & 3.2 & 3.7 & 3.2 & & \\
\hline
\end{tabular}


The protein-free diet contained glucose, starch, cellulose, rapeseed oil, vitamins and minerals. The wheat used in the current assay was produced in Jokioinen, Finland $\left(\mathrm{N} 61^{\circ} \mathrm{E} 23^{\circ}\right)$, whereas rapeseed meal and soybean meal were obtained from commercial suppliers (Avena Nordic Grain Ltd., Helsinki, Finland and Raisio Ltd., Raisio, Finland). Rapeseed meal was roller milled to flakes, heated $\left(83-90^{\circ} \mathrm{C}\right)$ and solvent extracted with hexane. Soybean meal was roller milled to flakes, heated $\left(50{ }^{\circ} \mathrm{C}\right)$, solvent extracted with hexane and heated to $100{ }^{\circ} \mathrm{C}$ before storing. Wheat was roller-milled with $4.0 \mathrm{~mm}$ sieve (Gehl Company, West Bend, Wisconsin, USA) before diet manufacturing. In all diets, $1.7 \mathrm{~g}$ of chromium mordanted straw was added at $0.2 \mathrm{~g} \mathrm{Cr} \mathrm{kg}^{-1}$ feed as an indigestible marker. After mixing all the ingredients, the experimental diets were cold-pelleted to $4 \mathrm{~mm}$ pellets (Amandus Kahl Laborpresse L175, Reinbek, Germany).

Table 2. Dietary ingredients $\left(\mathrm{g} \mathrm{kg}^{-1}\right)$ and chemical composition ( $\mathrm{g} \mathrm{kg}^{-1} \mathrm{dry}$ matter, unless otherwise stated) of experimental diets used in the ileal digestibility measurements

\begin{tabular}{|c|c|c|c|c|}
\hline & Wheat & Soybean meal & Rapeseed meal & Protein-free \\
\hline \multicolumn{5}{|l|}{ Dietary ingredients } \\
\hline Wheat & 861 & & & \\
\hline Soybean meal & & 430 & & \\
\hline Rapeseed meal & & & 585 & \\
\hline Glucose & 50 & 50 & 50 & 400 \\
\hline Starch & 0 & 430 & 238 & 414 \\
\hline Cellulose & 50 & 50 & 50 & 110 \\
\hline Rapeseed oil & 5 & 5 & 50 & 35 \\
\hline Monocalcium phosphate & 8 & 15 & 9 & 20 \\
\hline Limestone & 18 & 12 & 11 & 13 \\
\hline Salt & 3.8 & 3.8 & 3.4 & 4.0 \\
\hline Trace mineral premix ${ }^{\mathrm{a}}$ & 2.0 & 2.0 & 2.0 & 2.0 \\
\hline Vitamin premix ${ }^{b}$ & 2.0 & 2.0 & 2.0 & 2.0 \\
\hline Cr-mordanted straw ${ }^{c}$ & 1.7 & 1.7 & 1.7 & 1.7 \\
\hline \multicolumn{5}{|l|}{ Chemical composition } \\
\hline Dry matter $\left(\mathrm{g} \mathrm{kg}^{-1}\right)$ & 900 & 919 & 912 & 945 \\
\hline Crude protein & 129 & 204 & 210 & 8 \\
\hline Ether extract & 25 & 18 & 76 & 35 \\
\hline Crude fibre & 64 & 64 & 124 & 78 \\
\hline Ash & 38 & 53 & 62 & 36 \\
\hline \multicolumn{5}{|l|}{ Amino acids (g $\left.16 \mathrm{~g}^{-1} \mathrm{~N}\right)$} \\
\hline Lysine & 2.8 & 6.3 & 5.7 & \\
\hline Methionine & 1.5 & 1.3 & 1.9 & \\
\hline Threonine & 2.8 & 3.8 & 4.4 & \\
\hline Calculated metabolizable energy ( $\mathrm{MJ} \mathrm{kg}^{-1}$ ) & 12.4 & 12.3 & 11.0 & 15.6 \\
\hline
\end{tabular}

On day 32 posthatch, 4 replicate cages were randomly assigned to each of the 4 treatments for a 5-day digestibility assay. In order to determine the apparent ileal digestibility coefficients of wheat, rapeseed meal and soybean meal, experimental diets containing these ingredients were provided ad libitum to the birds for three consecutive days. After this period, the birds were fasted for 24 hours, and at the $5^{\text {th }}$ day of the assay, the birds had again a 4-h free access period to the same feeds. The basal ileal endogenous losses were determined in birds fed the protein-free diet to calculate standardized ileal digestibility coefficients. In $5^{\text {th }}$ day of assay, after 4 hours of feed consumption, all birds were stunned using carbon dioxide, euthanized by cervical dislocation and immediately dissected in order to minimize changes in digesta composition. The ileum was dissected from Meckel's diverticulum to the 
ileocecal junction. Digesta was collected from the distal half of the ileum to the ileocecal junction for further analysis. Digesta from birds from the same cage was pooled before chemical analysis. Birds were weighed at the beginning and end of the assay. The feed intake of each cage was recorded during the 4-h pre-slaughter feeding period.

Allfeed ingredients were sampled before diet preparation and experimental diets prior to beginning of the assay. Feed samples were dried at $60{ }^{\circ} \mathrm{C}$ overnight and ileal digesta samples were lyophilized during a period 3-4 days beginning at $-25^{\circ} \mathrm{C}$ and 0.370 mbar of pressure (Christ gamma 2-20 dryer with controller LMC-2, Martin Christ Gefriertrocknungsanlagen $\mathrm{GmbH}$, Osterode, Germany). All the samples were ground using a sample mill (Sakomylly KT-120, Koneteollisuus Oy, Klaukkala, Finland) and $1 \mathrm{~mm}$ sieve prior to analysis. Dried diets and ileal digesta samples were analysed for secondary dry matter (DM, $105^{\circ} \mathrm{C}$ for $16 \mathrm{~h}$ ), nitrogen, ether extract and total amino acid content. Nitrogen content in digesta was analysed according to a Dumas-based method using a Leco FP 428 nitrogen analyser (Leco Corp., St Joseph, USA). Ash and crude fat in feeds were analysed according to standard AOAC (1990) procedures (methods 942.05 and 920.39, respectively). Crude fibre was determined with a modified method of the AOAC method 962.09 using glass wool instead of ceramic fibre filter. Total (peptide bound and free) amino acid analysis was performed with Biochrom 20 amino acid analyser (Biochrom Ltd, Cambridge, England) using Sodium Buffer -system according to an official EC procedures (EC 1998). Chromium was determined by atomic absorption spectrometry (Williams et al. 1962). All the results are expressed on DM basis.

The apparent ileal digestibility coefficients were calculated using chromium as an indigestible marker as follows (Ravindran et al. 2005):

AID, $\%=\left[1-\left(\mathrm{CR}_{\text {Feed }} / \mathrm{CR}_{\text {Digesta }}\right) \times\left(\mathrm{AA}_{\text {Digesta }} / \mathrm{AA}_{\text {Feed }}\right)\right] \times 100$

where $\mathrm{Cr}_{\text {Feed }}$ is the chromium content in feed $\left(\mathrm{mg} \mathrm{kg}^{-1} \mathrm{DM}\right), \mathrm{Cr}_{\text {Digesta }}$ chromium content in digesta $\left(\mathrm{mg} \mathrm{kg}^{-1} \mathrm{DM}\right), \mathrm{AA}_{\mathrm{Di}-}$ gesta amino acid content in digesta $\left(\mathrm{g} \mathrm{kg}^{-1} \mathrm{DM}\right)$ and $\mathrm{AA}_{\text {feed }}$ the amino acid content in feed $\left(\mathrm{g} \mathrm{kg}^{-1} \mathrm{DM}\right)$.

The standardised ileal digestibilities were calculated from the apparent ones as follows (Adeola et al. 2016):

SID, \% = AID + (basal AA $\left.A_{\text {Digesta }} / \mathrm{AA}_{\text {Feed }}\right) \times 100$

where basal $A A_{\text {Digesta }}$ is the amino acid flow in the protein-free diet $\left(\mathrm{g} \mathrm{kg}^{-1} \mathrm{DM}\right.$ ) and calculated as follows (Adeola et al. 2016):

basal $A A_{\text {Digesta }}=A A_{\text {Digesta }} \times\left(\mathrm{Cr}_{\text {Feed }} / \mathrm{Cr}_{\text {Digesta }}\right)$.

The experimental data were analysed as one-way ANOVA using the GLM procedure of SAS (SAS Institute Inc., Cary, NC, USA) using a cage as the experimental unit. The statistical model included the fixed main effect of diet as follows:

$Y_{i j k}=\mu+d_{j}+e_{i j k}$

where $Y_{\mathrm{ijk}}$ is the dependent variable; $\mu$ is the overall mean; $d_{\mathrm{j}}$ is the fixed diet effect and $e_{\mathrm{ijk}}$ is the error term. The means were compared using the Tukey's multiple comparison test. Statistical effects were considered significant when $p<0.05$. In all cases, the residuals were plotted against fitted values to ensure normality of the experimental data.

\section{Results}

The broiler performance responses to experimental diets are detailed in Table 3 . The final live weight was not affected by the treatments $(p>0.05)$. The dry matter intake was higher in birds fed the soybean meal-based diet compared with birds fed the protein-free diet $(p<0.05)$. No differences in DM intake were noticed throughout the experimental period among the birds fed wheat, soybean and rapeseed based diets $(p>0.05)$. In addition, the DM intake at ileal digesta collection day was similar among all the experimental groups of birds $(p>0.05)$. 
Table 3. Live weight at the beginning (age $32 \mathrm{~d}$ ) and at the end (age $36 \mathrm{~d}$ ) of the experiment and average feed intake of broilers during the experiment and at the slaughter day ( $n=4$ per treatment).

\begin{tabular}{lcccccc}
\hline Diet & Wheat & $\begin{array}{c}\text { Soybean } \\
\text { meal }\end{array}$ & $\begin{array}{c}\text { Rapeseed } \\
\text { meal }\end{array}$ & $\begin{array}{c}\text { Protein-free } \\
\text { diet }\end{array}$ & SEM & $p$-value \\
\hline Live weight, g & & & & & & \\
At the beginning (age 32 d) & 1577 & 1603 & 1559 & 1574 & 17.9 & 0.402 \\
At the end (age 36 d) & 1717 & 1820 & 1796 & 1748 & 28.4 & 0.095 \\
Dry matter intake, g & & & & & & \\
$\quad \mathrm{d}^{-1}$ during experiment & $153^{\text {ab }}$ & $160^{\text {a }}$ & $154^{\text {ab }}$ & $146^{\text {b }}$ & 3.1 & 0.044 \\
$\quad$ during 4 h, at ileal digesta collection day & 88 & 82 & 79 & 71 & 5.7 & 0.247 \\
\hline
\end{tabular}

The AID values determined for the ingredients are presented in Table 4. The mean AID of amino acids in soybean meal and wheat were higher compared with rapeseed meal $(p<0.05)$ (Table 4.) Lysine AID was the highest in soybean meal and the lowest in rapeseed $(p<0.05)$ meal but it did not differ from that determined in wheat $(p>0.05)$. Methionine AID was similar among the ingredients $(p>0.05)$. Threonine AID was the highest in soybean meal, intermediate in wheat and the lowest in rapeseed meal $(p<0.05)$. Cystine AID was the highest in wheat and the lowest in soybean meal but did not differ from that in rapeseed meal $(p<0.05)$.

Table 4. Apparent ileal digestibility of amino acids (\%) in soybean meal, rapeseed meal and wheat measured with broilers ( $n=4$ per treatment)

\begin{tabular}{|c|c|c|c|c|c|}
\hline Diet & Soybean meal & Rapeseed meal & Wheat & SEM & $p$-value \\
\hline Mean & $81.4^{\mathrm{a}}$ & $75.8^{\mathrm{b}}$ & $81.7^{a}$ & 0.86 & 0.001 \\
\hline Alanine & $83.2^{\mathrm{a}}$ & $78.5^{b}$ & $79.0^{\mathrm{b}}$ & 0.80 & 0.004 \\
\hline Arginine & $88.9^{\mathrm{a}}$ & $84.7^{\mathrm{b}}$ & $81.8^{c}$ & 0.70 & $<0.001$ \\
\hline Aspartic acid & $78.9^{\mathrm{a}}$ & $72.4^{c}$ & $76.7^{b}$ & 0.93 & 0.002 \\
\hline Cystine & $57.2^{\mathrm{b}}$ & $59.6^{b}$ & $79.3^{\mathrm{a}}$ & 1.54 & $<0.001$ \\
\hline Glutamic acid & $83.3^{b}$ & $84.3^{b}$ & $90.1^{\mathrm{a}}$ & 0.91 & 0.004 \\
\hline Glycine & $77.6^{\mathrm{a}}$ & $72.4^{\mathrm{b}}$ & $77.1^{\mathrm{a}}$ & 0.90 & 0.005 \\
\hline Histidine & $84.2^{\mathrm{a}}$ & $80.4^{\mathrm{b}}$ & $81.0^{\mathrm{b}}$ & 0.70 & 0.008 \\
\hline Isoleucine & $84.3^{\mathrm{a}}$ & $75.4^{b}$ & $84.7^{\mathrm{a}}$ & 0.87 & $<0.001$ \\
\hline Leucine & $84.5^{\mathrm{a}}$ & $78.9^{b}$ & $85.5^{\mathrm{a}}$ & 0.85 & 0.001 \\
\hline Lysine & $88.3^{\mathrm{a}}$ & $80.5^{b}$ & $83.3^{\mathrm{b}}$ & 0.73 & 0.001 \\
\hline Methionine & $84.9^{\mathrm{a}}$ & $83.7^{\mathrm{a}}$ & $82.5^{\mathrm{a}}$ & 0.93 & 0.226 \\
\hline Phenylalanine & $85.9^{\mathrm{a}}$ & $79.4^{\mathrm{b}}$ & $86.0^{\mathrm{a}}$ & 0.86 & 0.001 \\
\hline Proline & $80.3^{\mathrm{b}}$ & $71.1^{c}$ & $87.9^{\mathrm{a}}$ & 1.02 & $<0.001$ \\
\hline Serine & $81.7^{\mathrm{a}}$ & $71.4^{\mathrm{b}}$ & $81.9^{\mathrm{a}}$ & 0.83 & $<0.001$ \\
\hline Threonine & $78.1^{\mathrm{a}}$ & $69.7^{c}$ & $74.1^{\mathrm{b}}$ & 0.96 & 0.001 \\
\hline Tyrosine & $81.4^{\mathrm{a}}$ & $72.0^{\mathrm{b}}$ & $75.9^{b}$ & 1.15 & 0.001 \\
\hline Valine & $81.5^{\mathrm{a}}$ & $73.8^{\mathrm{b}}$ & $82.3^{\mathrm{a}}$ & 1.02 & $<0.001$ \\
\hline
\end{tabular}

Values in the same row with different superscript differ significantly $(p<0.05)$. SEM = standard error of the mean

The ileal flow of amino acids is presented in Table 5. The lowest mean amino acid flow was noticed in broilers fed the protein-free diet $(p<0.05)$. The most abundant amino acids in the basal endogenous secretion were aspartic and glutamic acid and the least abundant ones were methionine and histidine. Among the groups of birds fed other ingredients than the protein-free diet, the mean amino acid flow was the highest in rapeseed meal, intermediate in soybean meal and the lowest in wheat $(p<0.05)$. Generally, the same pattern was noticed for the flow of individual amino acids, which increased gradually from wheat to soybean meal and further to rapeseed meal $(p<0.05)$, except for aspartic acid and glutamic acid, whose flow in soybean meal and rapeseed meal was similar $(p>0.05)$. In addition, soybean meal and wheat did not differ from each other with respect to methionine flow $(p>0.05)$. 


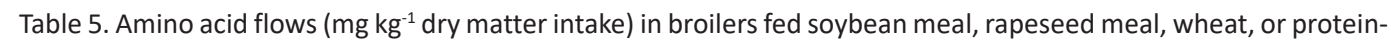
free diet ( $n=4$ per treatment)

\begin{tabular}{|c|c|c|c|c|c|c|}
\hline Amino acid & $\begin{array}{c}\text { Soybean } \\
\text { meal }\end{array}$ & $\begin{array}{c}\text { Rapeseed } \\
\text { meal }\end{array}$ & Wheat & $\begin{array}{l}\text { Protein-free } \\
\text { diet }\end{array}$ & SEM & $p$-value \\
\hline Mean & $1983^{b}$ & $2500^{a}$ & $1111^{c}$ & $296^{d}$ & 74.0 & $<0.001$ \\
\hline Alanine & $1446^{b}$ & $2001^{a}$ & $914^{c}$ & $241^{d}$ & 52.3 & $<0.001$ \\
\hline Arginine & $1586^{b}$ & $1904^{a}$ & $1061^{c}$ & $237^{d}$ & 66.2 & $<0.001$ \\
\hline Aspartic acid & $4691^{a}$ & $4290^{a}$ & $1466^{b}$ & $554^{c}$ & 143.3 & $<0.001$ \\
\hline Cystine & $1274^{b}$ & $1648^{a}$ & $641^{c}$ & $216^{d}$ & 47.0 & $<0.001$ \\
\hline Glutamic acid & $5643^{a}$ & $5000^{a}$ & $3511^{b}$ & $541^{c}$ & 270.0 & $<0.001$ \\
\hline Glycine & $1900^{b}$ & $2912^{a}$ & $1202^{c}$ & $319^{d}$ & 64.2 & $<0.001$ \\
\hline Histidine & $895^{b}$ & $1136^{a}$ & $607^{c}$ & $131^{\mathrm{d}}$ & 33.3 & $<0.001$ \\
\hline Isoleucine & $1427^{b}$ & $2052^{\mathrm{a}}$ & $707^{c}$ & $188^{d}$ & 60.1 & $<0.001$ \\
\hline Leucine & $2437^{b}$ & $3135^{a}$ & $1208^{c}$ & $282^{d}$ & 99.0 & $<0.001$ \\
\hline Methionine & $1494^{\mathrm{a}}$ & $2321^{a}$ & $605^{c}$ & $196^{d}$ & 58.0 & $<0.001$ \\
\hline Lysine & $407^{b}$ & $666^{\mathrm{a}}$ & $340^{b}$ & $108^{c}$ & 25.0 & $<0.001$ \\
\hline Phenylalanine & $1493^{b}$ & $1813^{a}$ & $834^{c}$ & $196^{d}$ & 67.3 & $<0.001$ \\
\hline Proline & $2072^{b}$ & $3465^{a}$ & $1552^{\mathrm{a}}$ & $360^{d}$ & 103.0 & $<0.001$ \\
\hline Serine & $1917^{b}$ & $2587^{a}$ & $1067^{c}$ & $341^{d}$ & 68.9 & $<0.001$ \\
\hline Threonine & $1710^{\mathrm{b}}$ & $2801^{a}$ & $924^{c}$ & $368^{d}$ & 57.6 & $<0.001$ \\
\hline Tyrosine & $1393^{b}$ & $1931^{a}$ & $962^{c}$ & $397^{d}$ & 52.2 & $<0.001$ \\
\hline Valine & $1931^{b}$ & $2840^{\mathrm{a}}$ & $1292^{c}$ & $365^{d}$ & 90.4 & $<0.001$ \\
\hline
\end{tabular}

Values in the same row with different superscript differ significantly $(p<0.05)$. SEM = standard error of the mean

The mean SID of amino acids in soybean meal and wheat were higher compared with rapeseed meal $(p<0.05)$ (Table 6). Lysine and threonine SID were higher in soybean meal and wheat compared to rapeseed meal $(p<0.05)$. Methionine SID was similar among ingredients $(p>0.05)$. Cystine SID was higher in wheat than in rapeseed meal and soybean meal $(p<0.05)$.

Table 6. Standardised ileal digestibility of amino acids (\%) in soybean meal, rapeseed meal and wheat measured with broilers ( $n=4$ per treatment)

\begin{tabular}{|c|c|c|c|c|c|}
\hline Diet & Soybean meal & Rapeseed meal & Wheat & SEM & $p$-value \\
\hline Mean & $84.6^{\mathrm{a}}$ & $78.8^{\mathrm{b}}$ & $87.2^{\mathrm{a}}$ & 0.86 & $<0.001$ \\
\hline Alanine & $86.0^{\mathrm{a}}$ & $81.1^{\mathrm{b}}$ & $84.5^{\mathrm{a}}$ & 0.80 & 0.005 \\
\hline Arginine & $90.6^{\mathrm{a}}$ & $86.6^{b}$ & $85.9^{b}$ & 0.70 & 0.002 \\
\hline Aspartic acid & $81.4^{a}$ & $75.9^{c}$ & $85.5^{\mathrm{a}}$ & 0.93 & $<0.001$ \\
\hline Cystine & $64.5^{\mathrm{b}}$ & $64.9^{\mathrm{b}}$ & $86.3^{\mathrm{a}}$ & 1.54 & $<0.001$ \\
\hline Glutamic acid & $84.9^{\mathrm{b}}$ & $86.0^{\mathrm{b}}$ & $91.6^{\mathrm{a}}$ & 0.91 & 0.001 \\
\hline Glycine & $81.3^{\mathrm{a}}$ & $75.4^{\mathrm{b}}$ & $83.1^{\mathrm{a}}$ & 0.90 & 0.001 \\
\hline Histidine & $86.5^{\mathrm{a}}$ & $82.6^{b}$ & $85.1^{\mathrm{ab}}$ & 0.70 & 0.010 \\
\hline Isoleucine & $86.4^{\mathrm{a}}$ & $77.7^{\mathrm{b}}$ & $88.8^{\mathrm{a}}$ & 0.87 & $<0.001$ \\
\hline Leucine & $86.3^{\mathrm{a}}$ & $80.8^{b}$ & $88.9^{a}$ & 0.85 & $<0.001$ \\
\hline Methionine & $88.9^{a}$ & $86.3^{\mathrm{a}}$ & $88.0^{\mathrm{a}}$ & 0.93 & 0.188 \\
\hline Lysine & $89.8^{\mathrm{a}}$ & $82.2^{\mathrm{b}}$ & $88.7^{\mathrm{a}}$ & 0.73 & $<0.001$ \\
\hline Phenylalanine & $87.7^{\mathrm{a}}$ & $81.6^{b}$ & $89.3^{\mathrm{a}}$ & 0.86 & $<0.001$ \\
\hline Proline & $83.7^{b}$ & $74.1^{\mathrm{c}}$ & $90.7^{a}$ & 1.02 & $<0.001$ \\
\hline Serine & $84.9^{\mathrm{b}}$ & $75.2^{c}$ & $87.7^{\mathrm{a}}$ & 0.83 & $<0.001$ \\
\hline Threonine & $82.8^{a}$ & $73.7^{\mathrm{b}}$ & $84.4^{\mathrm{a}}$ & 0.96 & $<0.001$ \\
\hline Tyrosine & $86.7^{\mathrm{a}}$ & $77.7^{b}$ & $85.9^{\mathrm{a}}$ & 1.15 & 0.001 \\
\hline Valine & $85.0^{\mathrm{a}}$ & $77.2^{\mathrm{b}}$ & $87.3^{\mathrm{a}}$ & 1.02 & $<0.001$ \\
\hline
\end{tabular}




\section{Discussion \\ The AID values of soybean meal, rapeseed meal and wheat}

The AID of amino acids in soybean meal were higher in Huang et al. (2006) and Frikha et al. (2012) than those determined in the current experiment. Conversely, De Coca-Sinova et al. (2008) reported lower AID of most amino acids in soybean meal. However, despite some variations for individual amino acids, the AID of amino acids in soybean meal determined in the current assay in general support previous research findings reported by Kong and Adeola (2013). In addition, AID of essential amino acids was similar in Adedokun et al. (2009), except that methionine and threonine AID were higher than in the current experiment. It could be noted that AID of cystine in the current experiment was remarkably lower compared to values reported in literature. However, de Coca-Sinova et al. (2008) also reported low values for AID of cystine in soybean meals from different origins.

Similarly to our previous findings (Perttilä et al. 2002), the values of amino acid AID in rapeseed meal determined in the current assay were lower than those in soybean meal. In general, despite some variations for individual amino acids, the AID of amino acids in rapeseed meal determined in the current assay support previous research findings reported by Newkirk et al. (2003), Huang et al. (2006) and Toghyani et al. (2015). Kasprzak et al. (2016) and Kasprzak et al. (2017) reported higher amino acid AID in most rapeseed batches, whose crude protein contents were higher than in rapeseed meals studied in the current experiment. However, Kasprzak et al. (2016) obtained identical amino acid AID in standard hexane extraction processed rapeseed meal as in our experiment, except for the AID of arginine and cystine which were slightly lower and lysine clearly higher than in our experiment. Gallardo et al. (2017) determined higher AID of lysine, threonine and aspartic acid and lower AID of cystine in rapeseed meal than in the current experiment.

Several reasons may explain the variation between the AID coefficients of amino acids determined in the present study and in published literature. Kasprzak et al. (2016) concluded that differences in rapeseed production conditions such as environment and varieties, oilseed crushing and extraction process and especially heat-treatment influence the contents of oil and protein, and digestibility in rapeseed meals and cakes, which might explain differences in digestibility results between previous and current experiments. Frikha et al. (2012) also concluded that differences between soybean products are attributed to growing conditions and the geographical location, heat-processing and steaming and therefore, nutritional value of soybean products are much more variable than previously assumed. In addition, De Coca-Sinova et al. (2008) concluded that differences in amino acid AID in literature may be attributed to differences in processing conditions, but also broiler age used and variations in feed intake between experiments.

Soybeans and rapeseeds are processed into oil, cake, and/or meal. The oil is extracted by high temperature and use of a solvent (solvent method) or by using steam (expeller method). Additionally, soybean and rapeseed products are processed to increase their nutritional value. Even though a heat treatment has proven to be necessary to remove or deactivate anti-nutritive factors of soybean and rapeseed products, heat exposure modifies protein and amino acid structure, which consequently impairs nitrogen and amino acid digestibility (Newkirk et al. 2003, Szczurek 2009, Toghyani et al. 2015).

Overheating has been shown to increase Maillard reactions, where heat-sensitive amino acids such as lysine bind to carbohydrates thus decreasing their availability. In the current experiment, both AID and SID values of lysine in rapeseed meal were lower compared with our previous report (Perttilä et al. 2002), which may have been due to the Maillard reactions during heat-processing. In addition, the values of AID and SID of cystine in soybean meal and rapeseed meal determined in the current assay were low. Because the disulphide bonds are very susceptible to heat exposure, cystine is considered the most heat labile of all amino acids.

In addition, trypsin inhibitors in soybeans and rapeseeds decrease trypsin activity and increase protein losses. According to De Coca-Sinova et al. (2008), apparent digestibility of cystine decreases in soybean products with high trypsin inhibitor content, because cystine content in trypsin is high and when the trypsin inhibitor binds trypsin, endogenous secretion of cystine is increased.

De Coca-Sinova et al. (2008) and Toghyani et al. (2015) also reported a negative correlation between neutral detergent fibre content and amino acids AID in soybean meal and rapeseed meal. The higher crude fibre content in rapeseed meal compared to soybean meal may explain its lower amino acid digestibility determined in the current assay. Unfortunately, the neutral detergent fibre content of soybean and rapeseed meal was not measured in the current experiment. 
The amino acid AID values in wheat were higher in our previous report (Perttilä et al. 2005) than in the current experiment except for cystine, whose AID was similar in both assays. Generally, the AID of amino acids in wheat determined in the current assay support previous values reported by Huang et al. (2006), except for lysine and tyrosine whose AID coefficients were lower and higher, respectively, than in our findings. Conversely, Bandegan et al. (2011) reported higher AID of most amino acids than determined in the current experiment, except again lower AID for lysine compared with our findings. However, Bandegan et al. (2011) determined a coefficient of variation of 0-3.9\% in individual amino acid digestibilities between wheat samples cultivated in different locations in western Canada. The crude protein content of them varied from 148 to $184 \mathrm{~g} \mathrm{~kg}^{-1} \mathrm{DM}$.

The crude protein content of the ingredients used by the aforementioned authors differed from the current experiment and there were differences in the contents and digestibility of individual amino acids of ingredients used. According to Rodehutscord et al. (2016), cereal grains of different genotypes differ in their chemical composition. Short et al. (1999) noticed that AID of amino acids increases in wheat as the crude protein increases. In addition, Zuber et al. (2017) noticed that the amino acid digestibility variation could be connected to the variable proportion and properties of various protein fractions. An increase in total wheat crude protein content is associated with a relative increase in storage proteins (rather than albumins and globulins), which contain relatively more of the nutritionally non-essential amino acids (Short et al. 1999).

In addition, differences in the digestibility of amino acids in the grains have been assumed to be caused by the differences in their fibre content and especially the differences in the contents of the anti-nutritive factors such as non-starch polysaccharides (Hughes and Choct 1999). Rodehutscord et al. (2016) reported that the variation in the soluble parts of $\beta$-glucans and arabinoxylans of wheat were high, the mean concentration of the soluble $\beta$-glucans and arabinoxylans being 2.0 and $13.9 \mathrm{~g} \mathrm{~kg}^{-1} \mathrm{DM}$, respectively. According to Angkanaporn et al. (1994), $\beta$-glucans and arabinoxylans decrease protein digestibility by impairing protein digestion, inhibiting amino acid absorption and increasing the secretion of the endogenous protein derived from the gut secretions and sloughed off epithelial cells to the digesta. In addition, digesta viscosity is increased (Choct and Annison 1992). Unfortunately, the content of non-starch polysaccharides was not measured in the current experiment.

\section{Endogenous amino acid excretion}

The predominant endogenous amino acids in digesta from the distal ileum of the protein-free diet fed broilers were aspartic acid and glutamic acid and the lowest ones present were methionine and histidine similarly as in Ravindran et al. (2004), Adedokun et al. (2007), Golian et al. (2008) and Kong and Adeola (2013). However, the concentrations of most amino acids were lower than in Ravindran et al. (2004) and Kong and Adeola (2013) and higher than in Adedokun et al. (2007) and Golian et al. (2008). In the current experiment, methionine and histidine showed the lowest endogenous secretion compared to Szczurek (2009), where methionine, tryptophan and cystine were the lowest ones.

Sources of endogenous amino acids are digestive secretions, mucoproteins, sloughed off intestinal epithelial cells, serum albumin and amides. The reason for variation in basal ileal endogenous flows of amino acids might be that gut mucin is degraded and renewed non-regularly. Observed discrepancy in amounts of endogenous secretions may also be partly explained by the measuring method such as the nature of the diet and starvation (Adedokun et al. 2011). In addition, Adedokun et al. (2007) reported that the age and species of birds influence the endogenous amino acid flow, which complicates comparisons of results with previous experiments. Further, Adedokun et al. (2011) noticed that electrolytic balance and ratio of starch and dextrose in the protein-free diet influenced the endogenous secretion and should be considered when SID of amino acids determined in different experiments are compared. Also, the type of fibre changes the viscosity, rate of digesta passage and mucin excretion and therefore, cellulose should be added to protein-free diets to maintain the normal water absorption, digesta viscosity and mucin secretion (Adeola et al. 2016).

\section{The SID values of soybean meal, rapeseed meal and wheat}

The SID of essential amino acids in soybean meal in the current experiment were higher than in Ravindran et al. (2017), but rather similar as in Adedokun et al. (2009), Szczurek (2009) and Kong and Adeola (2013). However, SID of almost all non-essential amino acids in soybean meal were higher in Adedokun et al. (2009). In addition, Frikha et al. (2012) determined higher amino acid SID in soybean meal than in the current experiment. 
In general, amino acid SID values in rapeseed meal in the current experiment were in agreement with Hoehler et al. (2006), Adedokun et al. (2009), Szczurek (2009), Gallardo et al. (2017), Kasprzak et al. (2017) and Osho et al. (2019), despite slight variation in SID of individual amino acids such as SID of cystine being lower and that of lysine higher in the current experiment. In a literature review about how different methods of measurement could influence the ileal digestibility of amino acids of rapeseed (canola) meal in broilers, Kong and Adeola (2011) reported similar values of amino acid SID as our findings. The aforementioned authors calculated SID of amino acids in rapeseed meal from Adedokun et al. (2007), where a protein-free diet was used. In Toghyani et al. (2015), SID of most amino acids were higher in rapeseed meal and in Woyengo et al. (2010), lower than in the current experiment.

In wheat, there was some variation in SID of individual amino acids, but in general, the SID of amino acids in the current experiment support previous research of Hoehler et al. (2006) and Bandegan et al. (2011). In contrary, Osho et al. (2019) reported lower amino acid SID in wheat and Szczurek (2009) lower SID of other amino acids except a higher histidine SID than in the current experiment.

\section{Differences in AID and SID values of amino acids in soybean meal, rapeseed meal and wheat}

Different AID for individual amino acids in previous experiments compared to the current experiment can be partly explained by differences in individual amino acid endogenous secretions. According to Adedokun et al. (2011) the basal amino acid losses are related to the amount of DM intake but otherwise unrelated to dietary composition. Specific endogenous secretions are influenced by diet composition.

In addition, Bandegan et al. (2011) measured amino acids AID and SID in wheats ranging in crude protein content from 148 to $184 \mathrm{~g} \mathrm{~kg}^{-1} \mathrm{DM}$ and concluded that increasing wheat crude protein content increased amino acid AID as the endogenous secretion compared to crude protein intake decreased with increased wheat crude protein content.

High dietary protein concentration increases secretion of digestive enzymes while fibre and anti-nutritional factors change the viscosity and passage rate of ileal digesta influencing the secretion of mucin and epithelial cell turnover resulting in increased specific endogenous secretion and decreasing AID of amino acids. Therefore, difference between AID and SID of amino acids are smaller in highly digestible raw materials like soybean and rapeseed than in for example maize (Adedokun et al. 2008).

\section{Conclusions}

Overall, the AID and SID values of amino acids in soybean meal and wheat were higher compared with rapeseed meal. The difference between amino acid AID and SID values was higher for wheat than for soybean and rapeseed meal, which did not differ from each other. The outcomes obtained from the current research can be utilized in future data compilations to update Feed tables for poultry. Under commercial conditions, such information could be used by poultry industry to design more precise feeding programmes to increase the efficiency of dietary amino acid utilization by poultry, which may potentially decrease feed costs and mitigate environmental $\mathrm{N}$ excretion.

\section{References}

Adedokun, S.A., Parsons, C.M., Lilburn, M.S., Adeola, O. \& Applegate, T.J. 2007. Endogenous amino acid flow in broiler chicks is affected by age of birds and method of estimation. Poultry Science 86: 2590-2597. https://doi.org/10.3382/ps.2007-00096

Adedokun, S.A., Adeola, O., Parsons, C.M., Lilburn, M.S. \& Applegate, T.J. 2008. Standardized ileal amino acid digestibility of plant feedstuffs in broiler chickens and turkey poults using a nitrogen-free or casein diet. Poultry Science 87: 2535-2548. https://doi.org/10.3382/ps.2007-00387

Adedokun, S.A., Utterback, P., Parsons, C.M., Adeola, O., Lilburn, M.S. \& Applegate, T.J. 2009. Comparison of amino acid digestibility of feed ingredients in broilers, laying hens and caceotomised roosters. British Poultry Science 50: 350-358. https://doi.org/10.1080/00071660902951321

Adedokun, S.A., Adeola, O., Parsons, C.M., Lilburn, M.S. \& Applegate, T.J. 2011. Factors affecting endogenous amino acid flow in chickens and the need for consistency in methodology. Poultry Science 90: 1737-1748. https://doi.org/10.3382/ps.2010-01245

Adeola, O., Xue, P.C., Cowieson, A.J. \& Ajuwon, K.M. 2016. Basal endogenous losses of amino acids in protein nutrition research for swine and poultry. Animal Feed Science and Technology 221: 274-283. https://doi.org/10.1016/j.anifeedsci.2016.06.004 
Angkanaporn, K., Choct, M., Bryden, W. L., Annison, E. F. \& Annison, G., 1994. Effects of wheat pentosans on endogenous amino acid losses in chickens. Journal of the Science of Food and Agriculture 66: 399-404. https://doi.org/10.1002/jsfa.2740660319

AOAC 1990. Official methods of analysis. Associations of Official Analytical Chemists, Inc., Arlington, Virginia. 1141 p.

Bandegan, A., Golian, A., Kiarie, E., Payne, R.L., Crow, G.H., Guenter, W. \& Nyachoti, C.M. 2011. Standardized ileal amino acid digestibility in wheat, barley, pea and flaxseed for broiler chickens. Canadian Journal of Animal Science 91: 103-111. https://doi.org/10.4141/CJAS10076

Choct, M. \& Annison, G. 1992. Anti-nutritive effect of wheat pentosans in broiler chickens. British Poultry Science 33: 821-824. https://doi.org/10.1080/00071669208417524

Dari, R.L., Penz, A.M.Jr, Kessler, A.M. \& Jost, H.C. 2005. Use of digestible amino acids and the concept of ideal protein in feed formulation for broilers. Journal of Applied Poultry Research 14: 195-203.https://doi.org/10.1093/japr/14.2.195

De Coca-Sinova, A., Valencia, D.G., Jiménez-Moreno, E., Lázaro, R. \& Mateos, G.G. 2008. Apparent ileal digestibility of energy, nitrogen, and amino acids of soybean meals of different origin in broilers. Poultry Science 87: 2613-2623. https://doi.org/10.3382/ps.2008-00182

EC 1998. Commission Directive 98/64/EC establishing Community methods of analysis for the determination of amino acids, crude oils and fats, and olaquindox in feeding stuffs and amending Directive 71/393. EEC. Official Journal of European Community L257: 14-28.

Frikha, M., Serrano, M.P., Valencia, D.G., Rebollar, P.G., Fickler, J. \& Mateos, G.G. 2012. Correlation between ileal digestibility of amino acids and chemical composition of soybean meals in broilers at 21 days of age. Animal Feed Science and Technology 178: 103-114. https://doi.org/10.1016/j.anifeedsci.2012.09.002

Gallardo, C., Dadalt, J.C., Kiarie, E. \& Trindade Neto, M.A. 2017. Effects of multi-carbohydrase and phytase on standardized ileal digestibility of amino acids and apparent metabolizable energy in canola meal fed to broiler chicks. Poultry Science 96: 33053313. https://doi.org/10.3382/ps/pex141

Golian, A., Guenter, W., Hoehler, D., Jahanian, H. \& Nyachoti, C.M. 2008. Comparison of various methods for endogenous ileal amino acid flow determination in broiler chickens. Poultry Science 87: 706-712. https://doi.org/10.3382/ps.2007-00330

Hoehler, D., Lemme, A., Ravindran, V., Bryden, W.L. \& Rostagno, H.S. 2006. Feed formulation in broiler chickens based on standardized ileal amino acid digestibility. In: VIII Simposium Internacional de Nutrición Acuicola. Monterrey, Nuevo León, México. p. 197-212.

Huang, K.H., Li, X., Ravindran, V. \& Bryden, W.L. 2006. Comparison of apparent ileal amino acid digestibility of feed ingredients measured with broilers, layers and roosters. Poultry Science 85: 625-634. https://doi.org/10.1093/ps/85.4.625

Hughes, R. J. \& Choct, M. 1999. Chemical and physical characteristics of grains related to variability in energy and amino acid availability in poultry. Australian Journal of Agricultural Research 50: 689-701. https://doi.org/10.1071/AR98161

Kadim, I.T., Moughan, P.J. \& Ravindran, V. 2002. Ileal amino acid digestibility assay for the growing meat chicken - comparison of ileal and excreta amino acid digestibility in the chicken. British Poultry Science 44: 588-597.

Kasprzak, M.M., Houdijk, J.G.M., Kightley, S., Olukosi, O.A., White, G.A., Carre, P. \& Wiseman, J. 2016. Effects of rapeseed variety and oil extraction method on the content and ileal digestibility of crude protein and amino acids in rapeseed cake and softly processed rapeseed meal fed to broiler chickens. Animal Feed Science and Technology 213: 90-98. https://doi.org/10.1016/j.anifeedsci.2016.01.002

Kasprzak, M.M., Houdijk, J.G.M., Olukosi, O.A., Appleyard, H., Kightley, S.P.J., Carre, P. \& Wiseman, J. 2017. The influence of oil extraction process of different varieties on the ileal digestibility of crude protein and amino acids in broiler chickens. Animal Feed Science and Technology 227: 68-74. https://doi.org/10.1016/j.anifeedsci.2017.03.009

Kong, C. \& Adeola, O. 2011. Protein ultilization and amino acid digestibility of canola meal in response to phytase in broiler chickens. Poultry Science 90: 1508-1515. https://doi.org/10.3382/ps.2011-01363

Kong, C. \& Adeola, O. 2013. Additivity of amino acid digestibility in corn and soybean meal for broiler chickens and White Peckin ducks. Poultry Science 92: 2381-2388. https://doi.org/10.3382/ps.2013-03179

Lemme, A., Ravindran, V. \& Bryden, W.L. 2004. Ileal digestibility of amino acids in feed ingredients for broilers. World's Poultry Science Journal 60: 423-437. https://doi.org/10.1079/WPS200426

Maiorka, A., Dahlke, F., Santin, E., Kessler, A.M. \& Penz, A.M.Jr. 2004. Effect of energy levels of diets formulated on total or digestible amino acid basis on broiler performance. Brazilian Journal of Poultry Science 6: 87-91. https://doi.org/10.1590/S1516-635X2004000200003

Newkirk, R.W., Classen, H.L., Scott, T.A. \& Edney, M.J. 2003. The digestibility and content of amino acids in toasted and non-toasted canola meals. Canadian Journal of Animal Science 83: 131-139. https://doi.org/10.4141/A02-028

Osho, S.O., Babtunde, O.O. \& Adeola, O. 2019. Additivity of apparent and standardized ileal digestibility of amino acids in wheat, canola meal, and sorghum distillers dries grains with solubles in mixed diets fed to broilers. Poultry Science 98: 1333-1340. https://doi.org/10.3382/ps/pey457

Perttilä, S., Valaja, J., Partanen, K., Jalava, T. \& Venäläinen, E. 2002. Apparent ileal digestibility of amino acids in protein feedstuffs and diet formulation based on total vs digestible lysine for poultry. Animal Feed Science and Technology 98: 203-218. https://doi.org/10.1016/S0377-8401(02)00031-7

Perttilä, S., Valaja, J. \& Jalava, T. 2005. Apparent ileal digestibility of amino acids and metabolisable energy value in grains for broilers. Agricultural and Food Science 14: 325-334. https://doi.org/10.2137/145960605775897704

Ravindran, V., Hew, L.I., Ravindran, G. \& Bryden, W.L. 1999. A comparison of ileal digesta and excreta analysis for the determination of amino acid digestibility in food ingredients for poultry. British Poultry Science 40: $266-274$. https://doi.org/10.1080/00071669987692 
Ravindran, V., Hew, L.I., Ravindran, G. \& Bryden, W.L. 2004. Endogenous amino acid flow in the avian ileum: quantification using three techniques. British Journal of Nutrition 92: 217-223. https://doi.org/10.1079/BJN20041202

Ravindran, V., Hew, L.I., Ravindran, G., \& Bryden, W.L. 2005. Apparent ileal digestibility of amino acids in dietary ingredients for broiler chickens. Animal Science, 81: 85-97. https://doi.org/10.1079/ASC42240085

Ravindran, V., Adeola, O., Rodehutscord, M., Kluth, H., van der Klis, J.D., van Eerden, E. \& Helmbrecht, A. 2017. Determination of ileal digestibility of amino acids in raw materials for broiler chickens - results of collaborative studies and assay recommendations. Animal Feed Science and Technology 225: 62-72. https://doi.org/10.1016/j.anifeedsci.2017.01.006

Rodehutscord, M., Rükert, C., Maurer, H.P., Schenkel, H., Schipprack, W., Bach Knudsen, K.E., Schollenberg, M., Laux, M., Eklund, M., Siegert, W. \& Mosenthin, R. 2016. Variation in chemical composition and physical characteristics of cereal grains from different genotypes. Archives of Animal Nutrition 70: 87-107. https://doi.org/10.1080/1745039X.2015.1133111

Rostagno, H.S. \& Pupa, J.M.R. 1995. Diet formulation for broilers based on total versus digestible amino acids. Journal of Applied Poultry Research 4: 293-299. https://doi.org/10.1093/japr/4.3.293

Short, F.J., Wiseman, J. \& Boorman, K.N. 1999. Application of a method to determine ileal digestibility in broilers of amino acids in wheat. Animal Feed Science and Technology 79: 195-209. https://doi.org/10.1016/S0377-8401(99)00022-X

Siriwan, P., Bryden, W.L. \& Annison, E.F. 1994. Use of guanidinated dietary protein to measure losses of endogenous amino acids in poultry. British Journal of Nutrition 71: 515-529. https://doi.org/10.1079/BJN19940159

Szczurek, W. 2009. Standardized ileal digestibility of amino acids from several cereal grains and protein-rich feedstuffs in broiler chickens at the age of 30 days. Journal of Animal and Feed Sciences 18: 662-676. https://doi.org/10.22358/jafs/66440/2009

Ten Doeschate, R.A.H.M., Scheele, C.W., Schreurs, V.V.A.M. \& Van der Klis, J.D. 1993. Digestibility studied in broilers chicks: Influence of genotype, age, sex and method of determination. British Poultry Science 34: 131-146. https://doi.org/10.1080/00071669308417569

Toghyani, M., Rodgers, N., Iji, P.A. \& Swick, R.A. 2015. Standardized ileal amino acid digestibility of expeller-extracted canola meal subjected to different processing conditions for starter and grower broiler chickens. Poultry Science 94: 992-1002. https://doi.org/10.3382/ps/pev047

Williams, C.H., David, D. \& Riismaa, O. 1962. The determination of chromic oxide in faeces samples by atomic absorption spectrometry. Journal of Agricultural Science 59: 381-385. https://doi.org/10.1017/S002185960001546X

Woyengo, T.A., Kiarie, E. \& Nyachoti, C.M. 2010. Metabolizable energy and standardised ileal digestible amino acid contents of expeller-extracted canola meal fed to broiler chickens. Poultry Science 89: 1182-1189. https://doi.org/10.3382/ps.2009-00595

Zuber, T., Maurer, H.P., Möhring, J., Nautscher, N., Siegert, W., Rosenfelder, P. \& Rodehutscord, M. 2017. Variability in amino acid digestibility of triticale grain from diverse genotypes as studied in cecectomized laying hens. Poultry Science 95: 2861-2870. https://doi.org/10.3382/ps/pew174 